\title{
СУБ'ЄКТНО-КОГНІТИВНА КОНЦЕПЦІЯ САМОРЕГУЛЯЦІЇ НАВЧАННЯ ШКОЛЯРІВ ІЗ ЗАТРИМКОЮ ПСИХІЧНОГО РОЗВИТКУ
}

Леся Прохоренко, Інститут спеціальної педагогіки Національної академії педагогічних наук України, м. Київ, Україна, lesya-prohor@ukr.net

Представлено теоретичний план дослідження, що передбачав інтеграцію та спеціалізацію психологічних знань у галузі суб'єктно-діяльнісної теорії, виявлення структурнофункціональної специфріки саморегуляції, удосконалення інтерпретації саморегуляції як психічної діяльності особистості. Інтерпретовано поняття «саморегуляція навчальної діяльності», що розглядається як внутрішня діяльність учня, у якій мотиви і мета характеризують її як процес, переважно в суб'єктному вимірі; аналіз, синтез і узагальнення умов діяльності, що розв'язується, - характеризують саморегуляцію переважно у процесуальному аспекті, - як діяльність. Неперервний взаємозв'язок обох цих аспектів визначено одним із проявів цілісності системи саморегуляції. Дослідження й аналіз різних чинників, і їх зіставлення, дало змогу простежити всі сторони розвитку саморегуляції діяльності в процесі навчання дітей із затримкою психічного розвитку.

Ключові слова: саморегуляція, мотивація, самоконтроль, рефрлексія, концепція, школярі із затримкою психічного розвитку.

Леся Прохоренко, Институт специальной педагогики Национальной академии педагогических наук Украины, м. Киев, Украина, lesya-prohor@ukr.net

\section{Субъективно-когнитивная концепция саморегуляции обучения школьников с задержкой} психического развития

Теоретический план исследования предусматривал интеграцию и специализацию психологических знаний в области субъектно-деятельностной теории, выявление структурно-функциональной специфики саморегуляции, совершенствование интерпретации саморегуляции как психической деятельности личности. Интерпретировано понятие "саморегуляция учебной деятельности", которое рассматривается как внутренняя деятельность ученика, где мотивы и цели характеризуют ее как процесс, преимущественно в субъектном измерении; анализ, синтез и обобщение условий деятельности, - характеризуют саморегуляцию преимущественно в процессуальном аспекте, как деятельность. Непрерывная взаимосвязь обоих этих аспектов, рассматривается как один из проявлений целостности системы саморегуляции. Исследование и анализ различных фрактов, и их сопоставление, позволило проследить все стороны развития саморегуляции деятельности в процессе обучения детей с задержкой психического развития.

Ключевые слова: саморегуляция, мотивация, самоконтроль, рефрлексия, концепция, школьники с задержкой психического развития.

() Прохоренко Л., 2018 
Lesya Prokhorenko, Institute of Special Education the National Academy of Educational Sciences of Ukraine, Kyiv, Ukraine

\section{Subjective cognitive concept of self-regulatory study of schoolchildren with the delay of mental development}

The bases for the development of the concept were socio-cognitive and theoretical approaches to activities, which allowed creating a person-cognitive concept of self-regulation of education for schoolchildren with a delay in mental development. The theoretical study plan included the integration and specialization of psychological knowledge in the field of the theory of substantive activity, the identification of the structural and functional specificity of self-regulation and the improvement of the interpretation of self-regulation as a mental activity. The concept of «selfregulation of educational activity» is interpreted, which is considered as an internal activity of the child, where motives and goals characterize it as a process, mainly in a substantive dimension; analysis, synthesis and synthesis of learning actions - characterize self-regulation as a process of activity. The continuous relationship between these two aspects is considered as one of the manifestations of the integrity of the system of self-regulation. The study and analysis of various facts and their comparison made it possible to trace all aspects of the development of self-regulation in the process of teaching children with cognitive impairment. Taking into account individual peculiarities of the child, the program of correction and development of self-regulation of students with mental retardation is identified within the framework of the age norm.

Keywords: self-regulation, motivation, self-control, reflection, concept, schoolchildren with a delay of mental development.

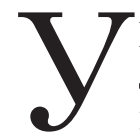

реалізації Державних програм, щодо надання спеціальної корекційної допомоги дітям з особливими освітніми потребами спрямованих на підвищення ефективності навчання дитини, формування ії пізнавальної активності і самостійності, пріоритетним напрямом є розроблення альтернативних шляхів здатності до саморегуляції навчальної діяльності учнів із затримкою психічного розвитку, що є підгрунтям створення інноваційних технологій навчання цих дітей.

Теоретичні аспекти проблеми саморегуляції представлені у низці досліджень з позиції психології особистості (Р. Бернс, Л. Виготський, У. Джеймс, В. Зінченко, Г. Костюк, О. Леонтьев, Б. Ломов, А. Матюшкін, Г. Нікіфоров, М. Розенберг, С. Рубінштейн, О. Тихомиров, З. Фрейд, В. Шадріков та ін.); у нейропсихології (П. Анохін, Ф. Гольц, О. Лурія, Ч. Шерінгтон, С. Хомська та ін.); на тлі соціогенетичної теорії (A. Bandura, G. Kelly, B. Skinner, C. Hull та ін.); в аспекті діяльнісного підходу (О. Асмолов, О. Конопкін, Ю. Кулюткін, Д. Леонтьєв, О. Леонтьєв, А. Маркова, М. Неймарк, Г. Нікіфоров, О. Осадько, О. Осницький та ін.. Досліджуючи різні психічні процеси і довільну регуляцію дій людини, вчені визнали, що первинною проблемою є не породження дії, а «оволодіння собою», тобто характерною тезою даних підходів є унікальна здатність людини до саморегуляції. 
У зарубіжних джерелах про саморегуляцію мовиться у межах психології особистості, психології регуляції діяльності, когнітивної психології (J. Atkinson, C. Hull, W. Kohler, E. Lowell, D. McClelland, G. Muller, H. Helmholtz, H. Heckhausen, E. Tolman та ін..). У психологічних дослідженнях саморегуляція розглядається як самоуправління довільними і вольовими діями, поведінкою, боротьба мотивів, встановлення їх супідрядності, планування діяльності, контроль за виконанням, корекція діяльності при необхідності.

На сучасному рівні наукових знань саморегуляцію розглядають як циклічний процес, в основі якого структурно-функціональні механізми спрямовані на самоуправління діяльністю (С. Максименко, Т. Матанцева, Л. Орбан-Лембрик, О. Осницкий, Л. Прохоренко, О. Прохоров, Ф. Райс, Т. Сак, Е. Толмен, A. Bandura, R. Baumeister, P. Dornerта ін.). За даними досліджень, саморегуляція формується в реальній діяльності людини і є одним із найважливіших механізмів регуляції діяльності.

У дефектології питання діяльності, поведінки, освіти, саморегуляції дітей різних нозологічних форм та категорій були предметом численних наукових досліджень (І. Гудим, О. Дробот, А. Замші, Г. Єфремової, В. Засенка, В. Кобильченка, В. Кісової, А. Колупаєвої, Г. Соколової, В. Лубовського, О. Романенко, Л. Руденко, Т. Сак, Т. Скрипник, О. Таранченко, О. Федоренко, С. Яковлевої та ін.).

У дослідженнях затримки психічного розвитку проблема саморегуляції дотично розглядалася в аспекті мотиваційно-особистісних і операційно-технічних складових схем навчальної діяльності (М. Басов, Л. Виготський, Д. Ельконін, В. Давидов, А. Маркова, П. Гальперін, С. Шацький та ін.); у рамках дослідження мотивації, цілепокладання, навчальних домагань дітей із затримкою психічного розвитку (далі ЗПР) (Є. Аксьонова, Т. Єгорова, В. Лубовський, Ю. Максименко, В. Подобєд, Т. Сак, П. Шошин); на тлі самоконтролю та самооцінки учнів iз ЗПР (Н. Голуб, Г. Жарєнкова, 3. Калмикова, І. Марковська, Ю. Максименко, Л. Прохоренко, В. Романко, У. Ульєнкова та ін.); як засіб корекції недоліків у інтелектуальному розвитку дітей із ЗПР (Н. Білопольська, С. Домішкевич, Т. Ілляшенко, О. Красило, А. Колупаєва, А. Обухівська, Т. Сак та ін.). У висновках досліджень відзначено, що у дітей з особливими освітніми потребами процеси цілепокладання, програмування та контролю не сформовані на належному рівні, функціонують з певними особливостями і є наслідком системного недорозвинення всіх психічних функцій, мотивації, самоконтролю та саморегуляції, що негативно відбивається на засвоєнні навчально-пізнавальної інформації.

Отже, специфічні особливості оволодіння навчальною діяльністю учнів із затримкою психічного розвитку обумовили доцільність створення нової концепції саморегуляції навчання, як зовнішнього механізму управління цією діяльністю, і внутрішнього, по-відношенню до суб'єкта діяльності, що передбачає розроблення відповідних напрямів іï діагностики та створення системи психокорекції.

Теоретико-медологічною основою розробки концепції саморегуляції навчальної діяльності школярів із ЗПР стали: системно-структурний підхід - вивчення внутрішніх зв'язків і залежностей між елементами системи саморегуляції, і визначення внутрішньої будови цієї системи; функціонально-рівневий підхід - вивчен- 
ня саморегуляції як системи різнорівневих функціональних психічних процесів; суб'єктно-діяльнісний підхід -аналіз саморегуляції як особистісного новоутворення, яке забезпечує узгодженість особистісних потреб, здібностей, очікувань з умовами та вимогами діяльності, побудовою діяльності відповідно до власних цілей і цінностей, iï удосконалення через з'ясування неузгодженостей, здійснення корекції; регуляційний підхід - вивчення психології саморегуляції як механізму опрацювання інформації та регуляції діяльності особистості; системний підхід комплексне дослідження системи саморегуляції, iї структурних компонентів як єдиного цілого із узгодженим функціонуванням усіх елементів і частин.

Визначені теоретичні позиції стали підгрунтям для створення теоретичної моделі дослідження, у якій процес саморегуляції представлений як система, що складається із взаємопов'язаних структурно-функціональних компонентів, в основі яких лежать мотиваційні та процесуальні механізми: цілепокладання, самоконтроль, самооцінка, рефлексія та самокорекція.

Системний опис психології саморегуляції здійснено засобами аналізу їі основних характеристик, та синтезу - створення функціонально-рівневої моделі саморегуляції в навчальній діяльності школярів із ЗПР, що дало можливість розширити іiі структуру та з'ясувати динаміку. У цій моделі, система саморегуляції обумовлена психодинамічними характеристиками взаємодії мотиваційних, когнітивних, мисленнєвих, вольових процесів, і спрямована на реалізацію та вдосконалення діяльності суб'єкта.

3'ясування характеристик процесу саморегуляції (цілепокладання, процесуальність, динамічність, безперервність), на тлі якого формуються механізми будь-якої психічної діяльності, дало змогу з'ясувати співвіднесення підсистем і системи саморегуляції загалом, та виявити ï специфіку в навчальній діяльності учнів із ЗПР не лише у статиці, а й у динаміці.

Механізм иілепокладання, виникнення мотиву. Цей механізм саморегуляції відображає як відбувається інтеграція процесуального та мотиваційно-особистісного аспектів. Потреба суб'єкта, яка виникає щодо розв'язання проблемного завдання чи ситуації, приводить до формування базової мотивації. Сформований мотив співвідноситься 3 проблемною ситуацією як образом зовнішнього завдання, який одночасно є і зовнішнім (об’єктивним) і внутрішнім (суб'єктним) утворенням. Залежно від того, який мотив був сформований і від особистісних властивостей суб'єкта, визначається становлення до проблемної ситуації, формується мета.

Прочесуальний механізм (самоконтроль, самооцінка, рефлексія, самокорекція). Мета породжує процесуальну сторону діяльності, яка характеризується певним діапазоном можливих способів іiї виконання (зоною невизначеності) й вибором конкретного способу реалізаціі. З'ясування типових положень по кожному із зазначених діапазонів зони невизначеності і результатом співвідношення зовнішніх вимог діяльності і внутрішніх умов суб'єкта відносно мети, в результаті чого відбувається зворотний вплив на мету. Прийняття умов виконання діяльності, реалізується через визначення способу їі розв'язання та втілення його практично. Зіставлення отриманих результатів з метою визначає шляхи корекції діяльності.

«ОСОБЛИВА ДИТИНА: навчання і виховання», № 4, 2018 
Неприйняття суб'єктом умов виконання діяльності веде до зміни мети, відбувається постановка нової мети, відповідно до неї формується новий алгоритм дій та прогнозуються нові результати нових дій. Коли вибір на цьому етапі здійснено, виникає мотив, який визначає спрямованість діяльності і завершує підготовчий перехід від мотивації до дії. Саме в контексті мотиваційної фази виступають значущими когнітивні процеси, які спрямовані на досягнення результатів дії, відбувається визначення необхідної інформації для подальшого втілення поставленої мети.

На завершальному етапі діяльності, знову активізуються мотиваційні процеси, які пов'язані з оцінкою досягнення наміченої мети, з'ясування міри їі виконання. Відбувається перегляд плану дій, передбачуваних результатів, які прогнозувалися на фазі мотивації, які зіставляються з фактичним ходом і результатами дій (самооцінка їх адекватності).

Таким чином, саморегуляцію ми розуміємо як психічне новоутворення суб'єкта, яке відображає пізнавальне та практичне відношення суб'єкта до дійсності. Саморегуляція як психічне новоутворення, у процесі здійснення діяльності виступає в якості внутрішніх їі умов, а також є чинником зміни самого суб'єкта і його психічного розвитку. Ми вважаємо, що лише цілісна структура саморегуляції, при достатній сформованості іiі функціональних компонентів і взаємозв'язків між ними, забезпечує ефективність навчальної діяльності.

Водночас, успішність та продуктивність навчальної діяльності залежить від рівня сформованості компонентів саморегуляції, що охоплюють: мотиви, які спрямовують діяльність особистості на всіх етапах iï розгортання, пошук найкращого шляху досягнення мети, складання алгоритму діяльності на основі аналізу конкретних умов, вибір способів дій і ї послідовність, практичну реалізацію, встановлення співвідношення запланованого, передбачуваного і досягнутого результату відповідно до мети, самокорекцію цієї діяльності.

Основні компоненти системи саморегуляції реалізуються конкретними регуляторними процесами, які мають специфічні функціі: мотивація - гіпотетичний, мисленнєвий конструкт, що забезпечує цілеспрямованість діяльності, початок і завершення дій; самоконтроль, самооцінка і самокорекція - забезпечують контроль за реалізацією запланованого, оцінювання отриманого результату, зіставлення з метою, корекцію тих змін, що відбуваються як у предметі діяльності, так і у самій особистості.

Сформований цілісний процес саморегуляції дає змогу самостійно ставити завдання щодо вдосконалення навчальної діяльності та саморозвитку.

Взаємодія психологічних механізмів саморегуляції під час виконання діяльності, з одного боку, залежить від детермінації мисленнєвої діяльності, розвитку психічних функцій особистості і від ставлення самої особистості до умов виконання діяльності, особистісного впливу на мету діяльності, що спонукає до перегляду та корекції мети, постановки нової мети та нового способу здійснення операцій діяльності.

Ефективність діяльності залежить від розвитку саморегуляції, що дає можливість особистості узгоджувати навчальні мотиви, контролювати перебіг діяльнос- 


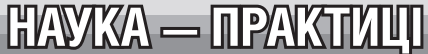

ті шляхом зіставлення наміченої програми зі здійснюваними діями, координувати та коректувати їі етапи і отримані результати.

Цілеспрямований розвивальний вплив на механізми саморегуляції створює позитивні умови для їх ефективного розвитку, що позитивно відображається на навчальній діяльності школяра (мал. 1). Як результат, механізми саморегуляції можуть розглядатися як механізми, які спрямовують і коректують навчальну діяльність.

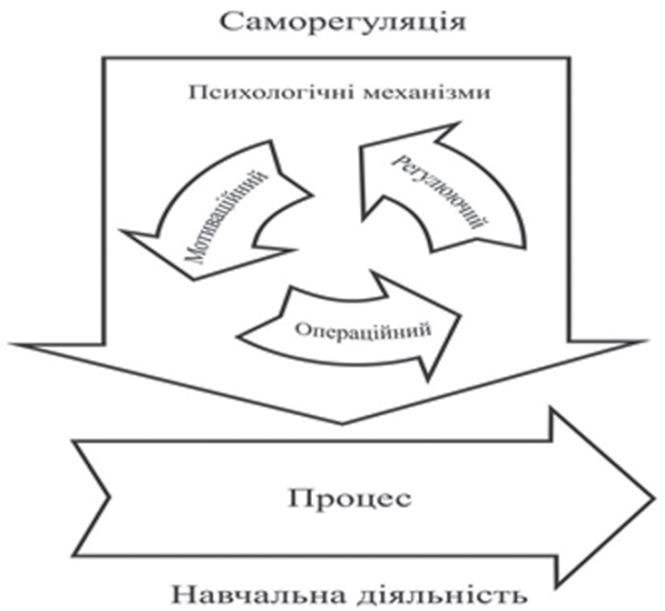

Мал. 1. Структура саморегулячї навчальної діяльності

Системо-утворюючою ланкою в цій структурі є мотиваційно-цільовий компонент. Відповідні потреби і мотиви спонукають до постановки мети діяльності, окреслюють відповідну область знань, яка водночас визначає методи і способи ї отримання. Потреба активізує діяльність учня, стимулює його, спрямовує на пошук способу досягнення мети, а ціль, дає змогу безпосередньо усвідомити результат, на який у конкретний момент спрямована дія, яка задовольняе актуальність навчальної потреби. Процеси установки і цілеспрямованості конкретизують вимоги до навчальної діяльності, визначають проміжні завдання у процесі досягнення іï загальної мети, актуалізують пізнавальні потреби в мотиваційній сфері і спрямовують учня на творчість.

Самоконтроль у структурі саморегуляції навчальної діяльності передбачає активну вольову участь і, реалізується через компетенції діяльності, засоби і способи діяльності: планування, проектування, моделювання, прогнозування, орієнтування в нових видах навчальної діяльності; управління за діяльністю: постановка і розв’язання завдань; побудова і розв'язання нестандартних, проблемних ситуацій. Тобто, пізнавальні дії виступають як операційні механізми навчальної діяльності.

У навчальній діяльності учень має здійснювати дії саморегуляції, які необхідні при вивченні будь-яких дисциплін: планування конкретних способів отримання необхідного результату, уявне виділення його етапів виконання, визначення способів виконанням, щоб досягти необхідного результату, уявлюваний образ 
результату, обгрунтування принципу дії, прогнозування варіантів дій, прийняття рішення, зокрема шляхом вибору раціонального варіанту дії, діагностика причин невідповідності (якщо вони є), визначення необхідної корекції вихідного плану. Так, у ході виконання цих дій учень повинен уявити собі об’єкт діяльності, кінцеву та проміжні цілі, мислительно на цій основі побудувати і спрогнозувати процес досягнення поставленої мети шляхом виділення в ньому складу дій, провести зіставлення виділених дій з повним ї складом, проаналізувати відмінності і пов'язані з ними особливості виконання завдання, їх вплив на об'єкт навчальної діяльності, тобто рефлексувати.

На етапі регулюючого компонента саморегуляції ефективність діяльності залежить від вибору способу і прийняття рішення, а саме: розкриття критеріїв оцінки діяльності щодо їх узагальненості й суттєвої диференціації, можливість «переглянути» інші варіанти, лише б ці дії дали можливість реалізувати вихідні плани і задуми. Тобто, особистість виконує рефлексивні дії: довільно конструює правила, припущення, ситуацію тощо, від яких залежить виконання діяльності, i «приміряє» іх на цю діяльність.

Отже, у нашій концепції саморегуляція виступає як психічне новоутворення суб'єкта, яке відображає пізнавальне та практичне відношення суб'єкта до діяльності. Саморегуляція як психічне новоутворення в процесі здійснення діяльності виступає в якості внутрішніх їі умов, а також є чинником зміни самого суб'єкта і його психічного розвитку. Ми вважаємо, що лише цілісна структура саморегуляції, при достатній сформованості їі функціональних компонентів і взаємозв'язків між ними, забезпечує ефективність навчальної діяльності.

Теоретичний план дослідження охоплює обгрунтований підхід до організації саморегуляції навчальної діяльності з орієнтацією на розвиток мотивації, самоконтролю, самооцінки, самокорекції та рефлексії. Перспективним, у прикладному аспекті, є розроблення технології саморегуляції навчальної діяльності школярів із ЗПР, у підгрунтя якої буде покладено структурно-змістові і динамічні особливості саморегуляції, що дасть змогу вдосконалити та розширити завдання діагностики та розвитку саморегуляції навчальної діяльності школярів із ЗПР шляхом дослідження мотивації, самоконтролю, самооцінки, самокорекції та рефлексії дитини в процесі навчання.

\section{ЛITEPATYPA}

1. Максименко С. Д. Психологічні механізми зародження, становлення та здійснення особистості / С. Д. Максименко, В. В. Клименко, А. В. Толстоухов. - Київ. Вид-во Європейського університету, 2010. - 152 c.

2. Матанцева T. Н. Психология саморегуляции и самооценки подростков с задержкой психического развития: учебное пособие / Т. Н. Матанцева, С. И. Смирнова. - Киров: ВятГГУ, 2010. - 163 с. 


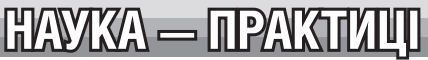

3. Прохоренко Л. І., Бужинеиька К. Б. Психологічні аспекти пізнавальної мотивації дітей 3 порушеннями когнітивного розвитку / Л. І. Прохоренко, К. Б. Бужинецька // Тези доповідей Міжнародної науково-практичної конференції «нклюзивне навчання в Новій українській школі» (26-27 березня 2018 року). - Теребовля: Інтерсервіс, 2018. - С. 184- 187.

4. Lesia Prokhorenko. Psycho - Correction of Motivation For Learning Achievements Among Schoolchildren With Cognitive Development Disorders. // Наука і освіта. - 2018. - №5. - 52-57.

5. Сак T. B. Індивідуалізація навчання учнів з особливими освітніми потребами в інклюзивному класі / Т. В. Сак // Особлива дитина: навчання і виховання. - 2014. - № 4. - С 18-23.

6. Соколова Г. Б. Актуальні питання психолого-педагогічного супроводу сімей, які виховують дитину з обмеженими можливостями здоров'я / Г. Б. Соколова // Актуальні питання корекційної освіти (педагогічні науки). Зб. Наукових праць. - Кам'янець-Подільський. 2016. - Вип.7, т.1. - С. 383-393.

\section{REFERENCES (TRANSLATED AND TRANSLITERATED)}

1. Maksymenko S. D. (2010). Psykholohichni mekhanizmy zarodzhennya, stanovlennya ta zdiysnenny aosobystosti, 152. [InUkrainian]

2. MatancevaT. N. (2010). Psixologiy asamoregulyaciii samoocenki podrostkov s zaderzhkoj psixicheskogo razvitiya: uchebnoe posobie, 163.[InRossiya]

3. Prokhorenko L. I. (2018). Buzhyneczka K.B. Psixologichni aspekti piznavalnoyi motyvaciyi ditej z porushennyamy kognitivnogo rozvitku, 184 - 187 [InUkrainian].

4. Lesia Prokhorenko. Psycho - Correction of Motivation For Learning Achievements Among Schoolchildren With Cognitive Development Disorders. // Наука і освіта. - 2018. - №5. - 52-57.

5. SakT. V. (2014). Indyvidualizatsiya navchannya uchniv z osoblyvymy osvitnimy potrebamy v inklyuzkhyvnomu klasi. Exceptional child: teaching and upbringing, 4, 18-23 [InUkrainian]

6. Sokolova, H.B. (2016). Aktualni pytannia psykholoho-pedahohichnoho suprovodu simei, yaki vykhovuiut dytynu z obmezhenym ymozhlyvostiamy zdorovia [Actual questions psychological and pedagogical support families raising a child with limited possibilities of health], 7, 383-393. [in Ukrainian]. 